Original article

\title{
Association of Socioeconomic Status and Pro-Environmental Behaviors in the Citizens of Gorgan, Iran (2017)
}

\author{
Danial Bagheri ${ }^{1}$, Reza Ali Mohseni ${ }^{2 *}$, Seyed Mohammad Sadegh Mahdavi ${ }^{3}$ \\ 1. PhD Candidate in Sociology, Islamic Azad University, Babol Branch, Babol, Iran. 0000- \\ 0002-8100-9204 \\ 2. Associate Professor, School of Humanities, Islamic Azad University, Central Tehran Branch, \\ School of Humanities, Islamic Azad University, Babol Branch, Babol, Iran \\ 3. Professor, School of Humanities, Islamic Azad University, Babol Branch, Babol, Iran. 0000- \\ $0002-1285-464 \mathrm{X}$
}

\begin{abstract}
Background and objectives: Environmental pollution is a major cause of various diseases. Massive production of hospital, industrial and household wastes lead to several health issues, threatening community health on a daily basis. The present study aimed to determine the association between socioeconomic status and pro-environmental behaviors in the citizens of Gorgan, Iran.

Methods: This cross-sectional, descriptive-analytical study was conducted on 400 citizens of Gorgan. Participants were divided into three regions based on urban categorization. Data were collected using demographic and socioeconomic questionnaires. To assess environmental behaviors, a standard questionnaire was used based on the Dunlap spectrum. Data analysis was performed in SPSS version 16 using the analysis of variance (ANOVA), independent samples t-test and factor analysis.
\end{abstract}

Results: No positive significant correlation was observed between gender and environmental behaviors. The results of ANOVA showed a significant association between marital status and environmental behaviors. In addition, the results of factor analysis indicated that five factors explained $55.49 \%$ of environmental behaviors. The results of ANOVA also demonstrated that middle-class citizens had a more responsible attitude toward the environment compared to others $(P<0.05)$.

Conclusion: According to the results, socioeconomic status influenced the social value orientations and responsible behaviors of individuals toward the environment. Therefore, increasing the quality of life and providing comprehensive education could enhance pro-environmental behaviors and promote community health.

Keywords: Socioeconomic status, Pro-Environmental behaviors, Ecological paradigm, Gorgan

Corresponding Author: Reza Ali Mohseni

Address: School of Humanities, Islamic Azad University, Central Tehran Branch, School of Humanities, Islamic Azad University, Babol Branch, Babol, Iran

E-mail: alireza1063@gmail.com 


\section{Introduction}

Environmental problems are among the most pressing issues faced by the human society in the modern era. Researchers have been concerned about finding sustainable solutions in this regard (1). The increasing trends of population growth and consumption rates are considered to be the main causes of excessive resource exploitation (2).

Prominent environmental sociology scholars, such as Dunlap and Van Liere (3), Dunlap and Jones (4), Ayodeji (5), Buttel (6), Schahn and Holzer (7) and Salehi (8) have investigated the influential factors on environmental behaviors including demographic characteristics (e.g., age, gender, social class, place of residence, marital status), political orientation, social ideology, environmental performance of nations, environmental knowledge and religious beliefs (9).

Pro-environmental behaviors are defined as the responses of community members to the environment, which involve a wide range of feelings, tendencies, and specific preparations for interacting with the environment. In every community, individuals have different attitudes to the environment based on their specific social and cultural conditions. In general, positive behaviors toward the environment are those not causing any harm, even if not protecting the environment (10).

Explaining responsible environmental behaviors is possible through reviewing the socioeconomic status and attitudinal and individual perceptions, as well as the opportunities available for environmental behaviors in communities. According to the literature, socioeconomic and cultural conditions play a pivotal role in the environmental behaviors of community members (11, 13). In addition, the socioeconomic status of community members largely influences the emergence of the proenvironmental behaviors that affect health. Due to the diversity of societies and profound impact of the society's structure and basic cultural factors in this regard, proper social relations and policymaking cannot be established (14).

On a large scale, the ability of organizations to manage solid waste is an effective component of health promotion. On the other hand, urban growth has currently imposed drastic pressure on the environment, as well as the health of community members. One of the most important consequences of this growth is migration to cities and the uncontrolled growth of suburbanization. In addition, individual factors play a key role in sustainable development.

The present study aimed to assess the knowledge and attitude of individuals toward energy use and waste recycling and investigate the association of socioeconomic status and pro-environmental behaviors in the citizens of Gorgan, Iran.

\section{Materials and Methods}

This descriptive-analytical research was conducted on 400 citizens (191 women and 209 men) in Gorgan, Iran in 2017. Data were collected using the field method. In addition, data collection tools included a self-report questionnaire including the occupation status, education level and social class of the subjects, with five main questions to assess the socioeconomic status (SES). Content and face validity of the questionnaire was confirmed by 12 experts, and its reliability was estimated at the Cronbach's alpha of 0.83 (15). The main data collection tool for assessing pro-environmental behaviors was 
based on the questionnaire by Stern (16) and Milfont and Duckitt (17).

Subjects were selected via random sampling. After determining the sample size using cluster sampling, the citizens of Gorgan were divided into three categories based on urban classification. All the questionnaires were anonymous, and data were collected directly from the citizens.

Data analysis was performed in SPSS version 16 using descriptive statistics (mean and standard deviation), inferential statistics (independent t-test for the mean comparison of the two groups), analysis of variance (ANOVA) and factor analysis. P-values lower than 0.05 were considered statistically significant.

\section{Results}

Among the participants, $52.2 \%$ were male and $47.8 \%$ were female. Mean age of the subjects was $33.31 \pm 9.69$ years (range $=17-62$ years). In terms of marital status, $31.8 \%$ of the participants were single, $55.5 \%$ were married and $12.7 \%$ were widowed or divorced. Regarding education status, $27 \%$ of the subjects had high school diploma or an associate degree, $48.3 \%$ were above diploma/had bachelor's degree and $24.7 \%$ had master's degree (or higher). In terms of occupation status, $39.3 \%$ were unemployed or job seekers, $10.7 \%$ had part-time jobs and $50 \%$ were employed (Table 1)

Table 1. Demographic Characteristics of Participants

\begin{tabular}{|c|c|c|c|}
\hline \multicolumn{2}{|c|}{ Variable } & Number & Percent (\%) \\
\hline \multirow{3}{*}{ Gender } & Female & 191 & 47.8 \\
\cline { 2 - 4 } & Male & 209 & 52.2 \\
\hline \multirow{4}{*}{ Age (year) } & $<20$ & 39 & 9.76 \\
\cline { 2 - 4 } & $21-30$ & 119 & 29.7 \\
\cline { 2 - 4 } & $31-40$ & 128 & 32.1 \\
\cline { 2 - 4 } & $41-50$ & 62 & 15.5 \\
\hline \multirow{3}{*}{$\begin{array}{c}\text { Marital } \\
\text { Status }\end{array}$} & $>50$ & 52 & 13.1 \\
\cline { 2 - 4 } & Single & 127 & 31.8 \\
\cline { 2 - 4 } Education & Married & 51 & 55.5 \\
\cline { 2 - 4 } Level & No Spouse & 108 & 27.7 \\
\cline { 2 - 4 } & Degree/Bachelor's Degree & 193 & 48.3 \\
\cline { 2 - 4 } & Master's Degree (or higher) & 99 & 24.7 \\
\hline \multirow{3}{*}{$\begin{array}{c}\text { Occupation } \\
\text { Status }\end{array}$} & Unemployed/Job Seeker & 157 & 39.3 \\
\cline { 2 - 4 } & Part-Time Job & 43 & 10.7 \\
\cline { 2 - 4 } & Full-Time Job & 200 & 50.0 \\
\hline
\end{tabular}


The results of independent samples t-test showed no significant difference between the male and female participants in terms of proenvironmental behaviors (Table 2).

Table 2. Comparison of Pro-Environmental Behaviors in Citizens Based on Gender

\begin{tabular}{|c|c|c|c|c|}
\hline Variable & $\begin{array}{c}\text { Gende } \\
\mathrm{r}\end{array}$ & $\begin{array}{c}\text { Mea } \\
\mathrm{n}\end{array}$ & $\begin{array}{c}\text { Standard } \\
\text { Deviatio } \\
n\end{array}$ & $\begin{array}{c}\text { P- } \\
\text { valu } \\
\mathrm{e}\end{array}$ \\
\hline \multirow{2}{*}{$\begin{array}{c}\text { Water } \\
\text { Consumptio } \\
n\end{array}$} & $\begin{array}{c}\text { Femal } \\
\mathrm{e}\end{array}$ & $\begin{array}{c}16.9 \\
7\end{array}$ & 4.31 & \multirow{2}{*}{0.82} \\
\hline & Male & $\begin{array}{c}16.8 \\
7\end{array}$ & 4.37 & \\
\hline \multirow{2}{*}{$\begin{array}{c}\text { Attitude } \\
\text { toward } \\
\text { Waste } \\
\text { Recycling }\end{array}$} & $\begin{array}{c}\text { Femal } \\
\mathrm{e}\end{array}$ & $\begin{array}{c}16.2 \\
9\end{array}$ & 3.96 & \multirow{2}{*}{0.56} \\
\hline & Male & $\begin{array}{c}16.0 \\
2\end{array}$ & 4.14 & \\
\hline \multirow{2}{*}{$\begin{array}{c}\text { Energy } \\
\text { Consumptio } \\
\mathrm{n}\end{array}$} & $\begin{array}{c}\text { Femal } \\
\mathrm{e}\end{array}$ & $\begin{array}{c}14.6 \\
4\end{array}$ & 3.34 & \multirow{2}{*}{0.82} \\
\hline & Male & $\begin{array}{c}14.5 \\
5\end{array}$ & 4.98 & \\
\hline \multirow{2}{*}{ Pollutants } & $\begin{array}{c}\text { Femal } \\
\mathrm{e}\end{array}$ & $\begin{array}{c}10.5 \\
5\end{array}$ & 2.78 & \multirow{2}{*}{0.92} \\
\hline & Male & $\begin{array}{c}10.5 \\
8\end{array}$ & 2.35 & \\
\hline \multirow{2}{*}{$\begin{array}{l}\text { Avoiding } \\
\text { Waste } \\
\text { Production }\end{array}$} & $\begin{array}{c}\text { Femal } \\
\mathrm{e}\end{array}$ & $\begin{array}{c}11.9 \\
5\end{array}$ & 2.71 & \multirow{2}{*}{0.76} \\
\hline & Male & $\begin{array}{c}12.0 \\
2\end{array}$ & 2.43 & \\
\hline
\end{tabular}

According to the results of ANOVA, there was a significant difference in the proenvironmental behaviors of the citizens in terms of the marital status. Married subjects received a higher score in pro-environmental behaviors in all the factors (water consumption, attitude toward waste recycling, energy consumption, pollutants, and avoiding waste production). Moreover, single subjects had a more efficient performance in this regard compared to those without a spouse (Table 3).
In the present study, environmental behaviors were the dependent variable in five dimensions of water consumption, attitude toward waste recycling, energy use, pollutants, and avoiding waste production with 20 items which were scored based on a Likert scale.

According to the information in Table 3, the results of ANOVA showed a correlation between the SES of the participants and water consumption. The level of water consumption was higher in the lower class compared to the middle class. In addition, citizens of high social classes had higher water consumption compared to the middle class. With regard to the attitude toward waste recycling, a correlation was observed between the SES of the respondents and their attitudes. On the other hand, citizens of the lower class had poor attitudes toward waste recycling. Citizens of the middle-class had better attitudes in this regard (mean: 16.76) compared to the higher class (mean: 16).

The results of ANOVA revealed an association between energy use and SES of the respondents. Correspondingly, lower class citizen wasted more energy than other social classes, while higher class citizens wasted less energy compared to the lower class citizens.

In the analysis of the fourth factor, a correlation was observed between the SES of the respondents and 'green behavior' (i.e., no use of pollutants), so that lower class citizens had the least consideration of using pollutants. According to the results of ANOVA, there was an association between the SES of the respondents and avoiding waste production. In this regard, lower class citizens produced the highest volume of waste, whereas the middle-class citizens produced the lowest level of waste (Table 4). 
Table 3. Comparison of Pro-Environmental Behaviors of Citizens Based on Marital Status

\begin{tabular}{|c|c|c|c|c|c|c|c|}
\hline Variable & Marital Status & Mean & $\begin{array}{l}\text { Standard } \\
\text { Deviation }\end{array}$ & $\begin{array}{l}\text { ANOVA } \\
\text { (Sig) }\end{array}$ & \multicolumn{3}{|c|}{ Tukey's Test (Sig) } \\
\hline \multirow{3}{*}{$\begin{array}{c}\text { Water } \\
\text { Consumption }\end{array}$} & Single & 15.68 & 4.32 & \multirow[t]{3}{*}{0.000} & 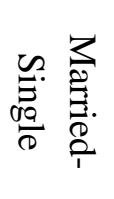 & 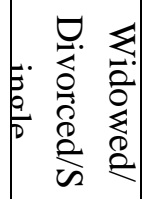 & 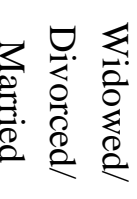 \\
\hline & Married & 18.35 & 3.90 & & \multirow{2}{*}{0.000} & \multirow{2}{*}{0.017} & \multirow{2}{*}{0.000} \\
\hline & No Spouse & 13.78 & 3.63 & & & & \\
\hline \multirow{3}{*}{$\begin{array}{c}\text { Attitude } \\
\text { toward Waste } \\
\text { Recycling }\end{array}$} & Single & 14.46 & 4.31 & \multirow{3}{*}{0.000} & \multirow{3}{*}{0.000} & \multirow{3}{*}{0.930} & \multirow{3}{*}{0.000} \\
\hline & Married & 17.53 & 3.50 & & & & \\
\hline & No Spouse & 14.23 & 3.37 & & & & \\
\hline \multirow{3}{*}{$\begin{array}{c}\text { Energy } \\
\text { Consumption }\end{array}$} & Single & 13.78 & 5.91 & \multirow{3}{*}{0.000} & \multirow{3}{*}{0.000} & \multirow{3}{*}{0.048} & \multirow{3}{*}{0.000} \\
\hline & Married & 15.63 & 2.90 & & & & \\
\hline & Widowed/divorced & 12.12 & 2.76 & & & & \\
\hline \multirow{3}{*}{ Pollutants } & Single & 9.96 & 2.54 & \multirow{3}{*}{0.000} & \multirow{3}{*}{0.000} & \multirow{3}{*}{0.014} & \multirow{3}{*}{0.000} \\
\hline & Married & 11.30 & 2.40 & & & & \\
\hline & No Spouse & 8.80 & 2.06 & & & & \\
\hline \multirow{3}{*}{$\begin{array}{l}\text { Avoiding } \\
\text { Waste } \\
\text { Production }\end{array}$} & Single & 10.85 & 3.00 & \multirow{3}{*}{0.000} & \multirow{3}{*}{0.000} & \multirow{3}{*}{0.626} & \multirow{3}{*}{0.000} \\
\hline & Married & 12.96 & 1.83 & & & & \\
\hline & No Spouse & 10.48 & 3.38 & & & & \\
\hline
\end{tabular}

In the current research, Bartlett's test of sphericity and Kaiser-Meyer-Olkin (KMO) measure of sampling were applied to evaluate the adequacy of the correlations between the variables. Considering that the KMO value was equal to 0.91 and more than 0.6 , it could be concluded that the correlation value was sufficient and the number of the samples to perform factor analysis was appropriate.

In the present study, the value of Bartlett's sphericity was 3176.229 at the significance level of 0.000 . Therefore, there was a correlation between the questions of each of the aforementioned factors and separation of the factors was carried out accurately. The factor loads were rotated using the Varimax method. In factor analysis, low level of antiimage correlation-coefficient was indicative of high, modified correlations between the variables. Therefore, factor analysis could be performed with a high reliability (Table 5).

The value of communalities, which is statistically equal to the coefficient of the regression model, demonstrated the accuracy and fitness of predicting each variable. The items regarding pro-environmental behaviors $(n=20)$ were reduced to five factors of water consumption, attitude toward waste recycling, energy use, pollutants, and avoiding waste production, and the total variance of these factors was estimated at 55.487. 
Table 4. Comparison of Pro-Environmental Behaviors in Citizens of Gorgan, Iran Based on Socioeconomic Status

\begin{tabular}{|c|c|c|c|c|c|c|c|c|}
\hline Variable & $\begin{array}{l}\text { Social } \\
\text { Class }\end{array}$ & Mean & $\begin{array}{l}\text { Standard } \\
\text { Deviation }\end{array}$ & F-value & $\begin{array}{l}\text { Analysis of } \\
\text { Variance } \\
(P \text {-value }) \\
\end{array}$ & $\begin{array}{r}\text { Com } \\
\text { Classes }\end{array}$ & $\begin{array}{l}\text { rison of } \\
\text { ith Tuk } \\
P \text {-value } \\
\end{array}$ & $\begin{array}{l}\text { ocial } \\
\text {,s Test }\end{array}$ \\
\hline \multirow{3}{*}{$\begin{array}{c}\text { Water } \\
\text { Consumption }\end{array}$} & $\begin{array}{l}\text { Lower } \\
\text { Class }\end{array}$ & 15.68 & 4.13 & \multirow{3}{*}{9.56} & \multirow{3}{*}{0.000} & $\frac{1}{2}$ & 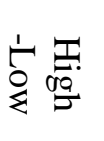 & 䓂茎: \\
\hline & $\begin{array}{l}\text { Middle } \\
\text { Class }\end{array}$ & 17.94 & 4.22 & & & \multirow{2}{*}{0.000} & \multirow{2}{*}{0.190} & \multirow{2}{*}{0.031} \\
\hline & $\begin{array}{c}\text { Higher } \\
\text { Class }\end{array}$ & 16.66 & 4.38 & & & & & \\
\hline \multirow{3}{*}{$\begin{array}{c}\text { Attitude } \\
\text { toward Waste } \\
\text { Recycling }\end{array}$} & $\begin{array}{c}\text { Lower } \\
\text { Class }\end{array}$ & 15.41 & 4.10 & \multirow{3}{*}{3.84} & \multirow{3}{*}{0.022} & \multirow{3}{*}{0.019} & \multirow{3}{*}{0.509} & \multirow{3}{*}{0.244} \\
\hline & $\begin{array}{l}\text { Middle } \\
\text { Class }\end{array}$ & 16.76 & 4.03 & & & & & \\
\hline & $\begin{array}{c}\text { Higher } \\
\text { Class }\end{array}$ & 16.00 & 3.94 & & & & & \\
\hline \multirow{3}{*}{$\begin{array}{c}\text { Energy } \\
\text { Consumption }\end{array}$} & $\begin{array}{c}\text { Lower } \\
\text { Class }\end{array}$ & 13.32 & 3.36 & \multirow{3}{*}{7.31} & \multirow{3}{*}{0.001} & \multirow{3}{*}{0.001} & \multirow{3}{*}{0.028} & \multirow{3}{*}{0.517} \\
\hline & $\begin{array}{l}\text { Middle } \\
\text { Class }\end{array}$ & 15.30 & 5.08 & & & & & \\
\hline & $\begin{array}{c}\text { Higher } \\
\text { Class }\end{array}$ & 14.75 & 3.51 & & & & & \\
\hline \multirow{3}{*}{ Pollutants } & $\begin{array}{c}\text { Lower } \\
\text { Class }\end{array}$ & 9.59 & 2.12 & \multirow{3}{*}{11.17} & \multirow{3}{*}{0.000} & \multirow{3}{*}{0.000} & \multirow{3}{*}{0.000} & \multirow{3}{*}{0.932} \\
\hline & $\begin{array}{l}\text { Middle } \\
\text { Class }\end{array}$ & 10.88 & 2.73 & & & & & \\
\hline & $\begin{array}{c}\text { Higher } \\
\text { Class }\end{array}$ & 10.99 & 2.47 & & & & & \\
\hline \multirow{3}{*}{$\begin{array}{l}\text { Avoiding } \\
\text { Waste } \\
\text { Production }\end{array}$} & $\begin{array}{c}\text { Lower } \\
\text { class }\end{array}$ & 11.35 & 2.84 & \multirow{3}{*}{6.22} & \multirow{3}{*}{0.002} & \multirow{3}{*}{0.001} & \multirow{3}{*}{0.211} & \multirow{3}{*}{0.176} \\
\hline & $\begin{array}{l}\text { Middle } \\
\text { Class }\end{array}$ & 12.45 & 2.27 & & & & & \\
\hline & $\begin{array}{l}\text { Higher } \\
\text { Class }\end{array}$ & 11.91 & 2.58 & & & & & \\
\hline
\end{tabular}

Table 5. Results of Factor Analysis Related to the Components of Environmental Behavior

\begin{tabular}{|c|c|c|c|}
\hline $\begin{array}{c}\text { Dependent } \\
\text { Variable }\end{array}$ & $\begin{array}{c}\text { Aspects of } \\
\text { Dependent Variables }\end{array}$ & $\begin{array}{c}\text { Explained } \\
\text { Variance }\end{array}$ & $\begin{array}{c}\text { Percentage of } \\
\text { Explained Variance }\end{array}$ \\
\hline \multirow{4}{*}{$\begin{array}{c}\text { Pro- } \\
\text { Environmental } \\
\text { Behaviors }\end{array}$} & Water Consumption & 12.781 & 55.487 \\
\cline { 2 - 4 } & $\begin{array}{c}\text { Attitude toward } \\
\text { Waste Recycling }\end{array}$ & 11.830 & \\
\cline { 2 - 4 } & Energy Consumption & 9.212 & \\
\cline { 2 - 4 } & Pollutants & 9.876 & \\
\cline { 2 - 4 } & $\begin{array}{c}\text { Avoiding waste } \\
\text { Production }\end{array}$ & 11.788 & \\
\hline
\end{tabular}




\section{Discussion}

Population growth and urbanization have caused numerous environmental problems, which pose a significant risk to human health (18). In this regard, the role of the social, economic, and cultural factors involved in the life of citizens of different social classes is of great importance. The present study aimed to evaluate the correlation between the SES and pro-environmental behaviors of the citizens in Gorgan city, Iran.

According to the results of the present study, the male and female subjects were homogeneous in terms of pro-environmental behaviors. This finding is in line with the results obtained by Haghighian (19) and Hajizadeh Meymandi et al. (23), while inconsistent with the findings of Mokhtari et al. (24). Most of the studies based on ecofeminism have proposed that women have better environmental behaviors compared to men, which was not confirmed in the present study.

In the current research, a significant correlation was observed between marital status and pro-environmental behaviors. Accordingly, married individuals had comparatively more responsible attitudes toward the environment in all the five factors (water consumption, attitude toward waste recycling, energy use, pollutants, and avoiding waste production). In this regard, our findings are in congruence with the results obtained by Karatasou (25) and Imam Gholi (23).

As a dependent variable, we divided environmental behaviors into five factors and separately evaluated the impact of all the SES components on these factors. According to the results, there was an association between SES and water consumption of the participants, which is in line with the studies by Salehi (26) and Ghaemi (37).
According to the current research, higher environmental attitudes were associated with better attitudes toward waste recycling. The results obtained by Abbaszadeh et al. (27), Amanpour (28), Best (29), and Czajkowski (30) also showed a positive correlation between the attitude of individuals toward the environment and pro-environmental behaviors.

In the present study, the components relating to energy consumption were combined and evaluated as a single factor. A significant correlation was denoted between energy consumption and the proenvironmental behaviors of the respondents, which is consistent with the results obtained by Karatasou (25), Karimzadeh, and Poortinga (31).

Similarly, the components relating to pollutants were integrated and evaluated as a single factor, and a significant association was observed between avoiding pollutants and pro-environmental behaviors in the participants. In this regard, the findings of Sajadian et al. (32), Tu and Lin (33), and Amanpour (28) were mainly focused on the development of cities and current pollutants in urban living.

In the present study, a significant association was observed between avoiding waste production and pro-environmental behaviors in the participants. This variable could partly demonstrate the sense of belonging of the citizens to the environment. In this regard, our findings are in line with the results obtained by Kalantari et al. (34), Aghaei (35), and Rastegarnejhad (36).

Findings of the current research indicated that human factors play a key role in the production and recycling of waste. On the other hand, the SES of individuals, including education level, occupation status, and perceptions of individuals toward the socioeconomic and cultural facilities of the society, could influence their values and 
responsible behaviors toward the

environment. Therefore, analysis and recognition of the attitudes and belongings of citizens could largely contribute to proper planning for waste management and recycling.

\section{Conclusion}

Many citizens in Gorgan city have a tendency to perform environmental behaviors, especially the middle class, which constitutes the largest population in Gorgan similar to other cities. However, these behaviors appear to be in conflict with the urban ecosystem due to the lack of knowledge and unwanted environmental behaviors. Therefore, it is possible to liberate human societies from the issues arising from the unsanitary disposal of solid wastes through establishing proper regulations and health-related programs and formulating sustainable development policies for collecting, separating, transporting, disposing, and recycling hospital, industrial, and household wastes.

\section{Acknowledgements}

This article was extracted from a doctoral dissertation on the Sociology of Economics and Development. Hereby (Code: 15620505961007), we extend our gratitude to all the citizens of Gorgan city for assisting us in this research project. 


\section{References}

1. Environmental Philanthropy and Environmental Behavior in Five Countries: Is There Convergence Among Youth? VOLUNTAS: International Journal of Voluntary and Nonprofit Organizations. August 2015, 26(4), pp 1485-1509

2. Carfagna, L. B., E. A. Dubois, C. Fitzmaurice, M. Y. Ouimette, J. B. Schor, and M. Willis. An emerging eco-habitus: the reconfiguration of high cultural capital practices among ethical consumers. Journal of Consumer Culture. 2014; 14:158-178.

3. Dunlap RE, Van Liere, KD. The new environmental Paradigm: A Proposed Measuring Instrument and Preliminary Results. J Environ Edu. 1978; 9: 10-19.

4. Dunlap RE, Jones RE. Environmental concern: conceptual measurement issues. Handbook of Environmental Sociology. Greenwood press, 2002: 482-524.

5. Ayodeji, I. Exploring secondary school students undesrstanding and practices of waste manangememnt in Ogum State Nigeria. International Journal of Environmental \& Science Education (2010): 5(2): 201-215.

6. Buttel F H. New directions in environmental sociology. Ann Rev Sociol.1987; 13: 465-88.

7. Schahn J, Holzer E. Studies of individual environmental concern: The role of knowledge, gender, and background variables. Environ Behav. 1990; 22: 767-86.

8. Salehi S. People and the environment. Lambert Academic Publication. 2010; 9: 17-29.

9. Ghaderi N, Choupani S, Salehi S, Khoshfar Gh. A Study of social factors affecting on environmental attitudes and behavior in the Marivan city in 2014. Zanko Journal of Medical Sciences. 2015: 16(48): 10-18. (Persian)

10. Fazeli M, Jafar Salehi S. The Gap between Attitude, Knowledge and Environmental Behavior of Tourists. Tourism Management Studies Journak. 2013: 22(8): 142-168. (Persian)

11. Hajizadehmeimandi M, Falakodin Z. A Survey of Socio-Cultural Factors Affecting Responsible Environmental Behavior (Case
Study: Citizens of Khorramabad). Journal of Social Development. 2017: 12(1): 7-36.(DOI): 10.22055/qjsd.2017.13046. (Persian)

12. Abbaszadeh M, Bani Fatemeh H, Alizadeh M B, Alavi L. Study of Intervening Effect of Environmental Responsible Attitude on the Relationship of between Place Attachment and Environmental Responsible Behavior. Journal of Applied Sociology. 2016: 27(2): 61-80. (Persian)

13. Bronfman N, Cisternas $\mathrm{P}$, López-Vázquez E, de la Maza C , Oyanedel J. Understanding Attitudes and Pro-Environmental Behaviors in a Chilean Community. Sustainability 2015: 7(10): 14133-14152; doi:10.3390/su71014133

14. Garmarudi, GH and Moradi A. The design measurement tool for socioeconomic status in Tehran. Payesh Quar. 2010; 2, 137-144. (Persian)

15. Eslami A, Mahmudi A, Khabiri M, NajafianRzavi SM. The role of socioeconmic status in motvating citizens to participate in recreational sports. J App Res Sport Management. 2013; 2(3), 89-104. (Persian)

16. Stern, C. P. Toward A Coherent Theory of Environmentally Significant Behavior. Journal of Social Issues, 2000: 56(3): 407-424.

17. Milfont, T. L. Duckitt, J. and Wagner, C. A Cross-Cultural Test of the Value-AttitudeBehavior Hierarchy. Journal of Applied Social Psychology. 2010: 40: 2791-2813.

18. Corina-Maria Ene, Anda Gheorghiu, Cristina Burghelea, Anca GheorghiuThe Conflict between Economic Development and Planetary Ecosystem in the Context of Sustainable Development. 6-th IASME/WSEAS International Conference on Energy \& Environment (EE'11), 2011,ISSN 17928230,ISBN 978-960-474-274-5: 266-271

19. Hghighian M. An Analysis of the Environmental Behavior of the Citizens of Isfahan and its Effective Factors. Journal of Urban Regional Studies and Research. 2014: 6(23): 133144 (Persian).

20. Hajizadehmeimandi M, Falakodin Z. A Survey of Socio-Cultural Factors Affecting Responsible Environmental Behavior (Case Study: Citizens of Khorramabad).Journal of social development. 2017: 12(1): 7-36 (Persian). DOI: $10.22055 /$ qj sd.2017.13046 
21. Ghaderi N, Choupani S, Salehi S, Khoshfar GH. A Study of social factors affecting on environmental attitudes and behavior in the Marivan city in 2014. Zanko J Med Sci 2015, 16(48): 10-18. (Persian).

22. Banifatemeh H, Rostaee SH, Alizadeh M, Hosinezadeh F. Density and Diversity of Bird Community in Hedgerows Surrounding Farmlands. Journal of environmental researches. 2014: 4(7): 173-186 (Persian).

23. Emamgholi L. The effect of social capital on environmental behavior (Case Study: Kurdistan Province). J Social Sci. 2011; 10: 58 - 69.

24. Mokhtari R, Abdollahi A, Sadeghi H. Analysis and Recognition of Urban Environmental Behaviors (Case Study: Isfahan City, 2012). Urban research and planning. 2014: 5(18): 1-20 (Persian).

25. Karatasou, S. Santamouris, M. Laskari, M. Models of behavior change and residential energy use: a review of research directions and findings for behavior-based energy efficiency. Advances in Building Energy Research. 2014: 8(2): 137-147. doi.org/10.1080/17512549.2013.809275

26. Salehi S. KArimnejad S. An Analysis on Relationship Between Environmental Values and New Environmental Attitudes (Case study: Urmia). 2014: 10(37): 153-170 (Persian).

27. Abbas zadeh M, Mirzaei H, Alyari L. The effect of cultural and social capital on citizens' participation in the segregation and collection of household waste studied by citizens of Urmia. Urban Socioogy. 2015: 5(14): 75-102 (Persian).

28. Amanpour S, Saedi J, Soleimani Rad E. Locating urban landfill, the city of Kermanshah Case Study Journal of Human and Environment. 2014: 11(27): 55-64 (Persian).

29. Best H, Mayerl J. Values, An empirical study on the Structure of Environmental Concern and Recycling Participation. Soc Sci Q. 2013; 94: 691-714.

30. Czajkowski M, Hanley N, Nyborg K. Social Norms, Morals and Self-interest as Determinants of Pro-environment Behaviours: The Case of Household Recycling. Environmental and Resource Economics. 2017: 66(4): 647-670.
31. Poortinga W, Steg L, Vlek C. Values, environmental concern, and environmental behavior: A study into household energy use. Environment and Behavior. 2004 Jan;36(1):70-93. Available from, DOI: $10.1177 / 0013916503251466$

32. Sajadian N, Nemati M, Daman Bagh S, Shojaeian A. An analysis of the rapid growth of urbanization and quality of life in the metropolis of Ahwaz. $\mathrm{J}$ of Geography and urbanization regional. 2016: 6(18): 187-214 (Persian).

33. T U, K.L. Lin, L. Evaluative Structure of Perceived Residential Environment Quality in High- Density and Mixed- use Urban Settings: An Exploratory Study on Taipei City, Landscape and Urban Planning: 2008:.87(3): 157-171.

34. Kalantari A, Kianpour M, Sharaf abadi, Lashgari M. Sociological Analysis of Sense of Belonging towards Nature (Case Study: Tehran Residents). Journal of Management system. 2016: 27(2): 1-16 (Persian).

35. Aghaei, M. Investigating the role of environmental culture of Isfahan citizens in the separation of domestic waste. Journal of social sciences. 2017: 10(34): 187-208 (Persian).

36. Rastegarkhaled A, Meshkini GH, Salehi, S. Investigate the Relationship between Individualism Collectivism and Environmental Citizenship among Citizens of Regions 3, 11 and 19 of Tehran. 2017: 12(1): 37-58 (Persian).

37. Ghaemi A. Preparing the model for environmental training to strengthen the sustainable governance of national water resources with an emphasis on public participation. scds 2016, 5(2): 133-157 (Persian). 


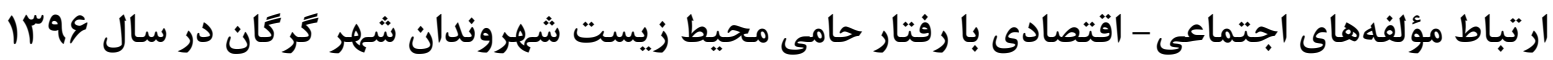

دانيال باقرى'، رضاعلى محسنى ז"، سيد محمدصادق مهدوى؟

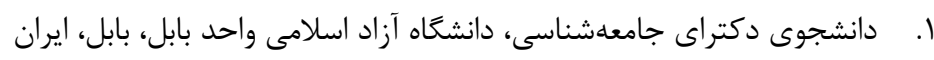

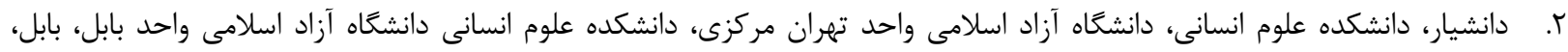

زمينه و هدف: آلودگى هاى زيست محيطى يكى از مههم ترين عوامل بروز بيمارىها است. توليد حجم انبوهى از زباله هاى بيمارستانى، صنعتى و خانكى به طور روزانه ايجاد كننده معضلات بهداشتى و تهديد كننده سلامت جوامع است. اين مطالعه به منظور تعيين ارتباط ئه متغيرهاى اجتماعى -اقتصادى با عملكرد زيست محيطى شهروندان شهر كر عان انجام شده است.

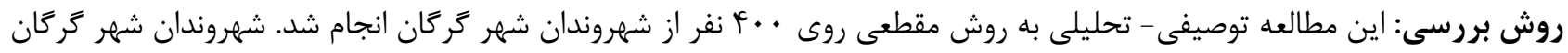
به r منطقه بر اساس تقسيم بندى شهرى تقسيم و اطلاعات دريافت شده مورد تجزيه و تحليل قرار كرفت. ابزارهاى مورد استفاده

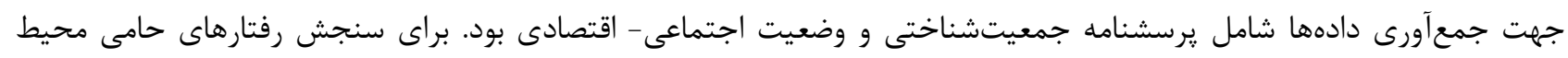

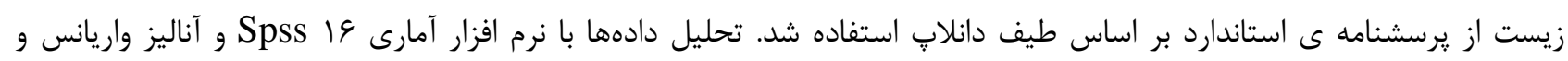
آزمون T مستقل و تحليل عاملى انجام شد.

يافته ها: نتايج تحقيق نشان داد بين جنسيت با رفتار حامى محيط زيست رابطه معنى دار و مثبتى وجود نداشت. تحليل واريانس

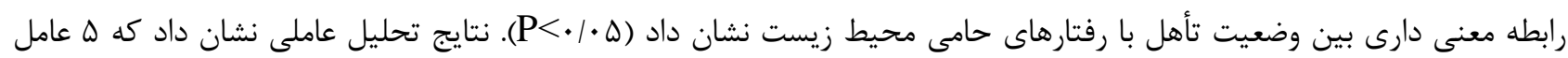

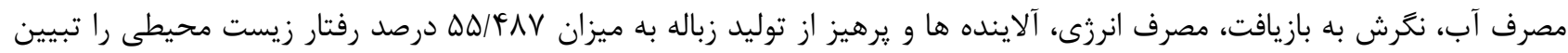

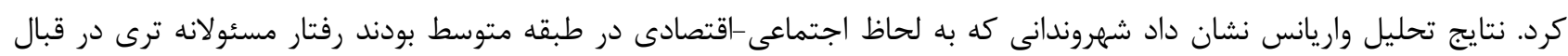

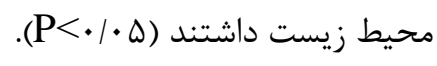

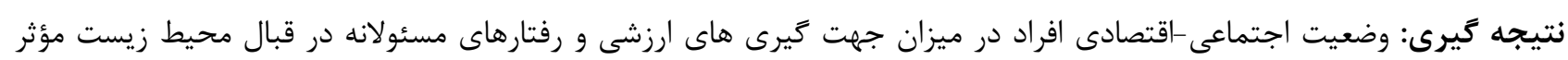

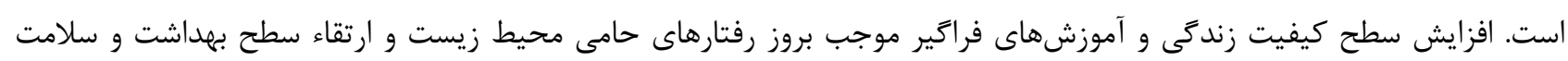
جامعه مى كلمات كليدى: مؤلفههاى اجتماعى - اقتصادى، رفتار زيست محيطى ، يارادايم نوين اكولوزيكى، شهر تركان نويسنده مسئول: رضاعلى محسنى آدرس: دانشگاه آزاد اسلامى واحد تهران مركزى محسئ تهران، ايران. ايميل: alireza1063@gmail.com 